\title{
14 Cycliophora-An Emergent Model Organism for Life Cycle Studies
}

\author{
Peter Funch
}

\section{CONTENTS}

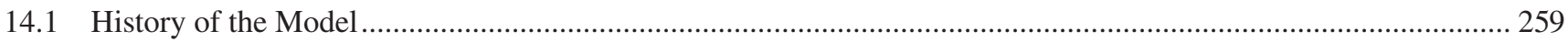

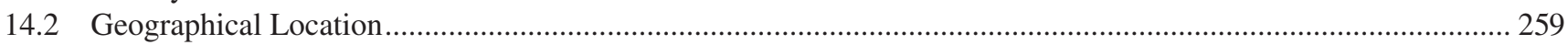

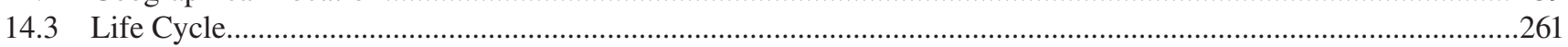

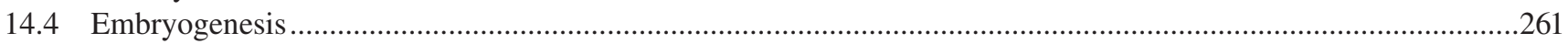

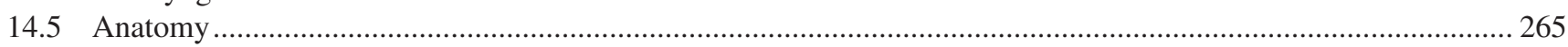

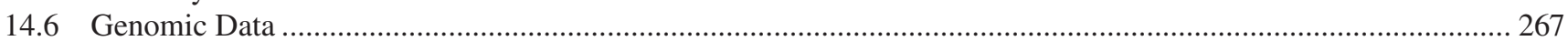

14.7 Functional Approaches: Tools for Molecular and Cellular Analyses.................................................................... 267

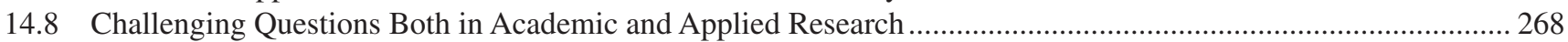

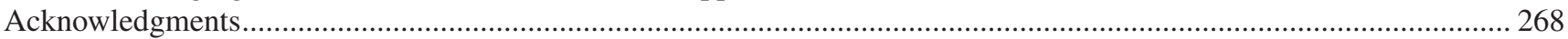

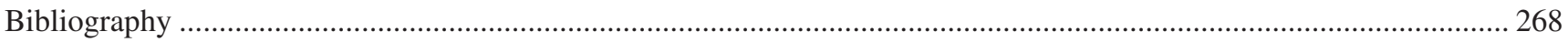

\subsection{HISTORY OF THE MODEL}

Cycliophora is a phylum of marine, microscopic, solitary epizoans found on the mouthparts of three common species of commercially exploited lobsters (Decapoda, Nephropidae) (Figures 14.1 and 14.2). Surprisingly, they were described as late as in 1995, but they were noticed already in the 1960s by Profs. Tom Fenchel and José Bresciani (Funch and Kristensen 1995; Funch and Kristensen 1997; Kristensen 2002; Funch and Neves 2019). At that time, cycliophorans were regarded as aberrant rotifers and got the nickname "Mysticus enigmaticus". Prof. Claus Nielsen at the Zoological Museum in Copenhagen then collected mouth parts from $N$. norvegicus with cycliophorans and prepared this material for ultrastructural studies. He kindly handed the embedded material to the author to be included in his master thesis project (Andersen 1992). Transmission electron microscopy of this material revealed that the cycliophorans had a welldeveloped cuticle very different from the syncytial integument with an intracytoplasmic lamina known form rotifers (Clément and Wurdak 1991). This observation lead to more extensive studies of ultrastructure, life cycle and host range (Andersen 1992).

To date, only two species have been formally described. The first studies showed that cycliophorans have an elaborate life cycle with a number of morphologically distinct stages that involve alternations between attached and free stages and asexual and sexual cycles (Funch and Kristensen 1995; Funch and Kristensen 1997) (Figure 14.3). The first species, Symbion pandora (Funch and Kristensen 1995), was described from the Norway lobster, Nephrops norvegicus, from Scandinavian waters, but before this description, a similar epibiont, still undescribed, was found on the mouthparts of the European lobster, Homarus gammarus (Andersen 1992; Funch and Kristensen 1997). The second described cycliophoran species, Symbion americanus, occurs on the American lobster, Homarus americanus (Obst et al. 2006), but cycliophorans from this host species are more genetically diverse due to the presence of at least three cryptic lineages (Obst et al. 2005; Baker et al. 2007; Baker and Giribet 2007). A study on S. pandora on N. norvegicus showed that this epizoan species is an obligatory commensal that depends on microscopic food particles generated during host feeding (Funch et al. 2008). Cycliophorans have also been found attached to harpacticoid copepods in a study of cycliophorans from European lobsters (Neves et al. 2014), but how common this association is and if it has any role in assisted migration of the cycliophorans is unclear. The integument including gills and mouth parts of a broader range of crustaceans-for example, Cancer pagurus, Carcinus maenas, Pagurus bernhardus, Geryon trispinosus, Galathea sp., Hyas sp. and Munida sp.-were examined for Cycliophora but did not reveal any (Andersen 1992). Also, a survey on a broader range of crustaceans from museum material only recovered cycliophorans on nephropid hosts (Funch and Kristensen 1997; Plaza 2012).

\subsection{GEOGRAPHICAL LOCATION}

Thus far, cycliophorans are known from coastal areas of the North Atlantic Ocean and the Mediterranean Sea where their decapod hosts also occur. The first known observations of cycliophorans from the 1960s were from mouthparts of Nephrops norvegicus from Kattegat, Denmark, and later the Gulf of Naples, Italy (pers. comm. Tom Fenchel and José Bresciani). The type locality for Symbion pandora is 


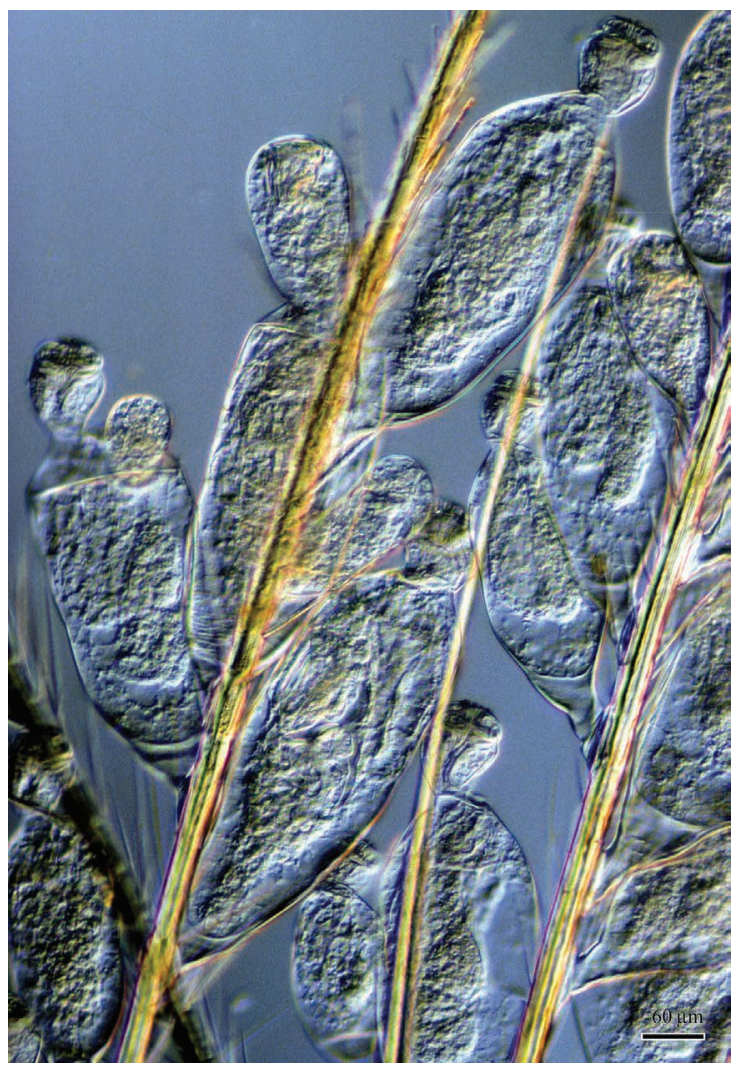

FIGURE 14.1 Sessile feeding stages of Symbion pandora on the setae of Nephrops norvegicus. DIC.

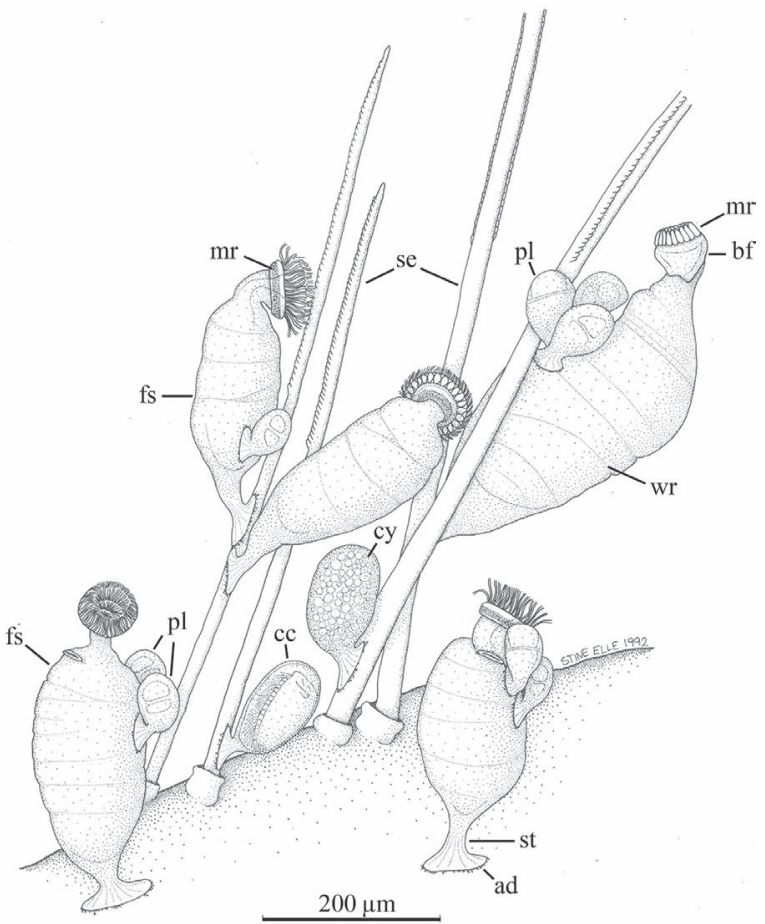

FIGURE 14.2 Various attached life cycle stages of Symbion pandora, type material. The cycliophorans are attached to the endopod of the first maxilla of Nephrops norvegicus. In the front are two feeding stages (fs) with an open mouth ring (mr) in feeding position and two Prometheus larvae (pl) attached on the trunk. Two cyst-like stages are attached to the bases of the setae. The one to the left is a chordoid cyst (cc) that contains a chordoid larva with ventral ciliation and a chordoid organ. The cyst-like stage (cy) to the right contains undifferentiated cells. Distally on the same seta is a larger feeding stage with a closed mouth ring and three attached Prometheus larvae. On the rightmost seta are two feeding stages with open mouth ring. The one to the left has an attached Prometheus larva-the right one has none. ad, adhesive disc; bf, buccal funnel; se, seta from the host; st, stalk; wr, wrinkles. (Reproduced with permission from Andersen 1992.) 
NW Kattegat, Denmark at 20-40 m of depth. In 1992, the known geographic range was extended to the coastal areas around the Faroe Islands (on fixed material collected in 1990 in Kaldbak Fjord), Orkney Islands and Southern Norway, and the host range was extended to include Homarus gammarus with an undescribed cycliophoran species (Andersen 1992). Nedved (2004) also reported the occurrence of cycliophorans on Homarus gammarus from the Adriatic Sea. The third cycliophoran species, Symbion americanus, was described from the mouth parts of the American lobster, Homarus americanus, collected from Maine and Cape Cod at the Northeast Atlantic coast of the United States (Obst et al. 2006). A phylogeographic study of the cycliophorans mentioned previously based on the mitochondrial gene COI indicated that the three species of cycliophorans were reproductively isolated on the three different hosts and that the free stages in the life cycle of cycliophorans have limited dispersal abilities (Obst et al. 2005). This study also showed a high genetic diversity of Symbion americanus and a low genetic diversity of $S$. pandora, and it was suggested that the latter species was of recent origin.

\subsection{LIFE CYCLE}

The life cycle of Cycliophora involves metagenesis with multiple stages and alternations between sessile stages that are permanently attached to a host and motile and free stages (Funch and Kristensen 1995; Funch 1996; Funch and Kristensen 1997) (Figure 14.3). The most prominent stage of the life cycle is the feeding stage, so named because it is the only stage in the life cycle with feeding structures and a digestive tract (Figure 14.4). Feeding stage individuals are often densely aggregated on the mouth parts of their decapod hosts and live on food particles collected by filter feeding (Figure 14.1). When a feeding stage individual grows, it continually forms internal new zooids with new feeding structures and gut, and these structures replace the structures associated with the old zooid (Figure 14.4). Larger and older feeding stage individuals also produce motile stages inside brood chambers (Funch and Kristensen 1997) (Figure 14.3). One feeding stage forms one motile stage in a brood chamber at a time, and it seems like asexual Pandora larva are produced first, then Prometheus larvae and finally females (Kristensen and Funch 2002). All motile stages are without a digestive tract.

The asexual part of the life cycle involves young feeding stage individuals that develop Pandora larvae in brood chambers (Figure 14.5). The Pandora larva is characterized by a ciliated locomotory disc and developing feeding structures inside. When mature, it escapes from the maternal feeding stage brood chamber and moves actively on the decapod host to seek a site on the mouth parts where it settles. This attached cyst-like stage then develops into a new small feeding stage when the internal feeding structures emerge (Funch and Kristensen 1997) (Figure 14.3).

The sexual part of the life cycle is initiated when smaller stages, the Prometheus larvae, are produced in the brood chambers of older feeding stages (Figures 14.3 and 14.6). Like the Pandora larva, the Prometheus larva uses a ciliated disc for locomotion, but contrary to the Pandora larva, it settles on the trunk of a cycliophoran feeding stage. Often, several Prometheus larvae are found on the same feeding stage individual. The preferred site for settlement is close to the cloacal opening of the feeding stage, and during settlement, a Prometheus larva typically orients itself with the posterior end as close to the cloacal opening as possible, directing the anterior end toward the attachment site of the feeding stage (Figures 14.4A and 14.6). Settlement involves secretion from gland cells that exits in the area of the ciliated disc and becomes an attachment disc. Dwarf males are produced inside the attached Prometheus larva, and one, two and three males have been observed developing simultaneously.

Females are produced inside the oldest feeding stages and are characterized by the presence of one oocyte (Figure 14.6). After escape from the maternal feeding stages, the females can be recognized by the presence of a single zygote (Figure 14.7). Females and Pandora larvae are almost similar in size, and females also use an anteroventral ciliated disc for locomotion when they are liberated from the brood chamber, and they settle on the mouth parts of the host. However, the preferred sites for settlement differ. Females prefer the lateral parts and articulations of the mouth parts of the host, while Pandora larvae prefer those medial segments of the mouth parts where availability of food particles is rich during host feeding (Obst and Funch 2006; Funch et al. 2008). When females settle, they degenerate and develop into chordoid cysts consisting of a female body cuticle containing a chordoid larva inside. These cysts and larvae are named after the presence of a characteristic longitudinal structure of similar vacuolated muscle cells (Figures 14.2 and 14.8). A chordoid larva has more locomotory ciliation compared to the other motile stages in the life cycle and has therefore been suggested to be a dispersal stage between hosts. This larval stage is capable of both crawling and swimming and is completely ciliated ventrally, including body ciliation separated from a ciliated foot. It has been suggested that the chordoid larva settles on the mouth parts of a host and develops into a small feeding stage, thereby completing the sexual life cycle (Figure 14.3) (Funch and Kristensen 1995).

\subsection{EMBRYOGENESIS}

In Cycliophora, the embryos are brooded inside females, but the type of cleavage is unknown, and polar bodies have never been observed. The zygote develops into a chordoid larva (Figure 14.8). The female develops one oocyte before it is liberated from the brood chamber of the feeding stage (Figure 14.6), and the first cleavage has been observed in a free-swimming female of Symbion pandora (Funch 1996), while an embryo consisting of four micromeres and four macromeres has been observed in a female after settlement (Neves et al. 2012). Based on these limited observations, it seems like cleavage is holoblastic. So, females that recently 


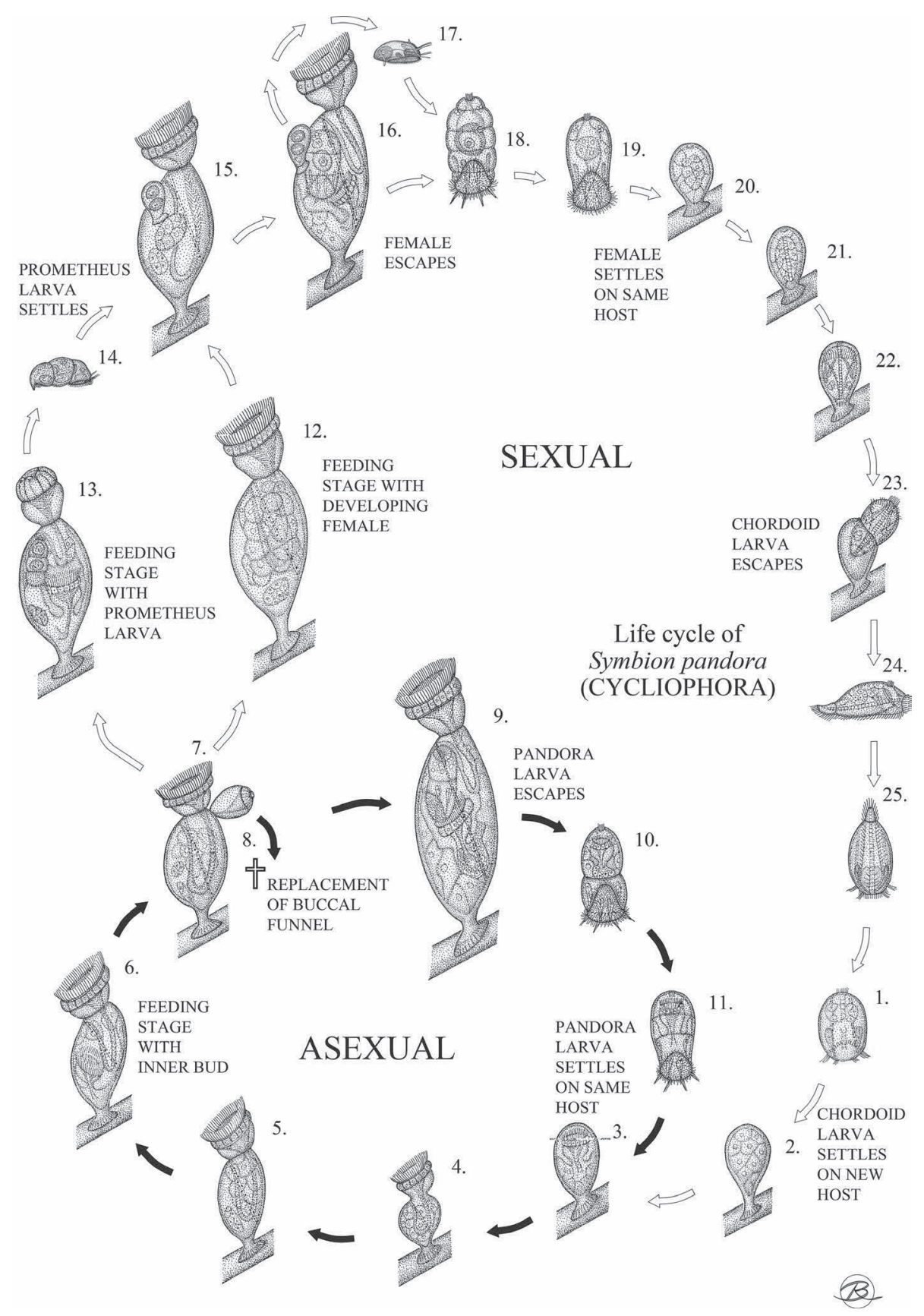

FIGURE 14.3 Proposed life cycle of Symbion pandora. The asexual cycle begins when a chordoid larva settles on the lobster host (1-2) and degenerates, while internal buds inside differentiate into feeding structures (3). The buccal funnel emerges, and filter feeding is enabled (4). The feeding stage then grows, and budding cells basally form a new zooid inside with a new buccal funnel, digestive tract and nervous system $(5,6)$. The new zooid replaces the old zooid (8). A larger and older feeding stage regenerates and replaces the feeding structures in a similar way but also forms a Pandora larva asexually inside a brood chamber (9). The fully developed Pandora larva then escapes the maternal feeding stage (9-10) and settles nearby on the host mouthparts (11-3). The larval structures degenerate, while the internal feeding structures matures, completing the asexual part of the life cycle (3). The factors involved when shifting to the sexual cycle are unknown, but the sexual part of the cycle involves older feeding stages that produce either one Prometheus larva (13) or one female (12) inside a brood chamber. When the Prometheus larva escapes, it settles (14) on the trunk of a feeding stage (15). Dwarf males develop inside the attached Prometheus larva from internal buds, while the female is produced inside the feeding stage (16). The fully mature dwarf male (17) might transfer the sperm during the release of the female or shortly afterward (18). Early cleavages have been observed before the female (19) settles on the mouthparts of the host (20). The female degenerates, while the internal embryo develops into a chordoid cyst (21). The chordoid larva escapes (23) and perhaps migrates $(24,25)$ to a new lobster host, where it settles on the mouthparts (1-2). Here budding cells inside develop into feeding structures while the larva degenerates (2-3), completing the sexual life cycle. (Material modified from: Peter Funch and Reinhardt Møbjerg Kristensen, Cycliophora is a new phylum with affinities to Entoprocta and Ectoprocta, Nature, published 1995, Nature Publishing Group.) 
(a)

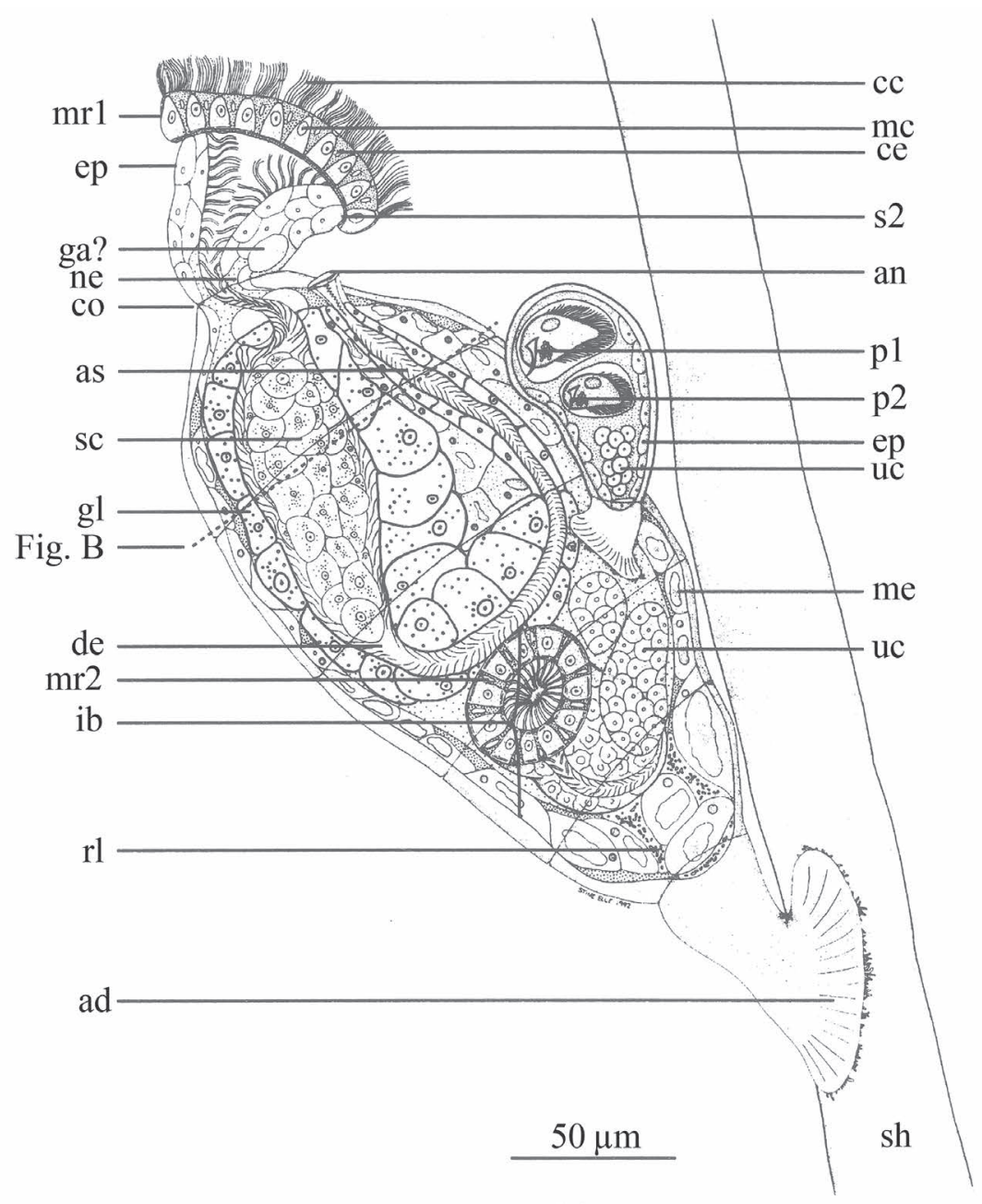

(b)

(c)
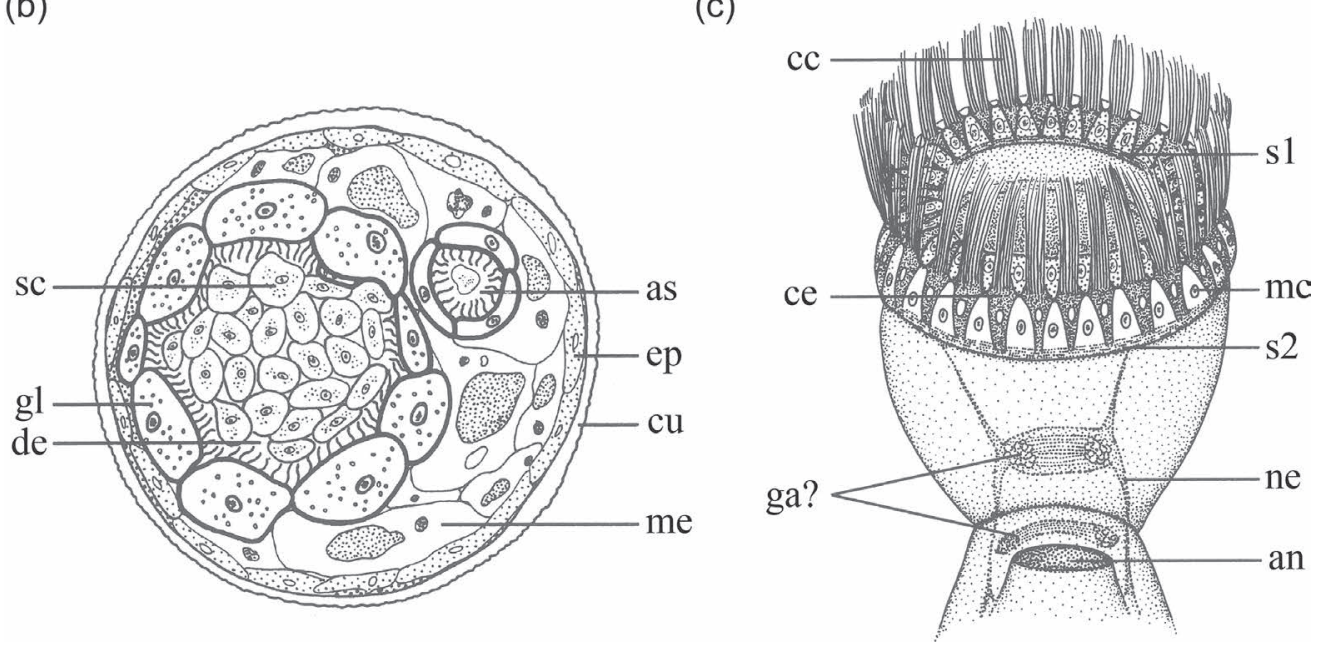

FIGURE 14.4 Symbion pandora. (a) Feeding stage individual (holotype) with attached Prometheus larva (allotype) attached to a seta of a mouthpart from Nephrops norvegicus. The mouth ring is in the everted feeding position. (b and c) Feeding stage individual. (b) Trunk in transverse section. (c) Buccal funnel with an everted mouth ring. Position of the nervous system is indicated. ad, adhesive disc; an, anus; as, ascending branch of the digestive tract; cc, compound cilia of the mouth ring; ce, ciliated epidermis; co, constriction (or "neck"); $\mathrm{cu}$, cuticle; de, descending branch of digestive tract; ep, epidermis; ga, ganglion; gl, gut lining cell; ib, inner bud; mc, myoepithelial cell; me, mesenchyme; mr, mouth ring; ne, nerve; p, penis; rl, remnants of larval glands; sc, stomach cells; sh, seta from the host; s, sphincter; uc, undifferentiated cells. ([a] Material modified from Funch and Kristensen, Cycliophora is a new phylum with affinities to Entoprocta and Ectoprocta, Nature, published 1995, Nature Publishing Group; [b and c] Reproduced with permission from Funch and Kristensen, Cycliophora. In Microscopic Anatomy of Invertebrates, edited by F. W. Harrison and R. M. Woollacott, 409-474. New York etc.: WileyLiss Inc., published 1997.) 


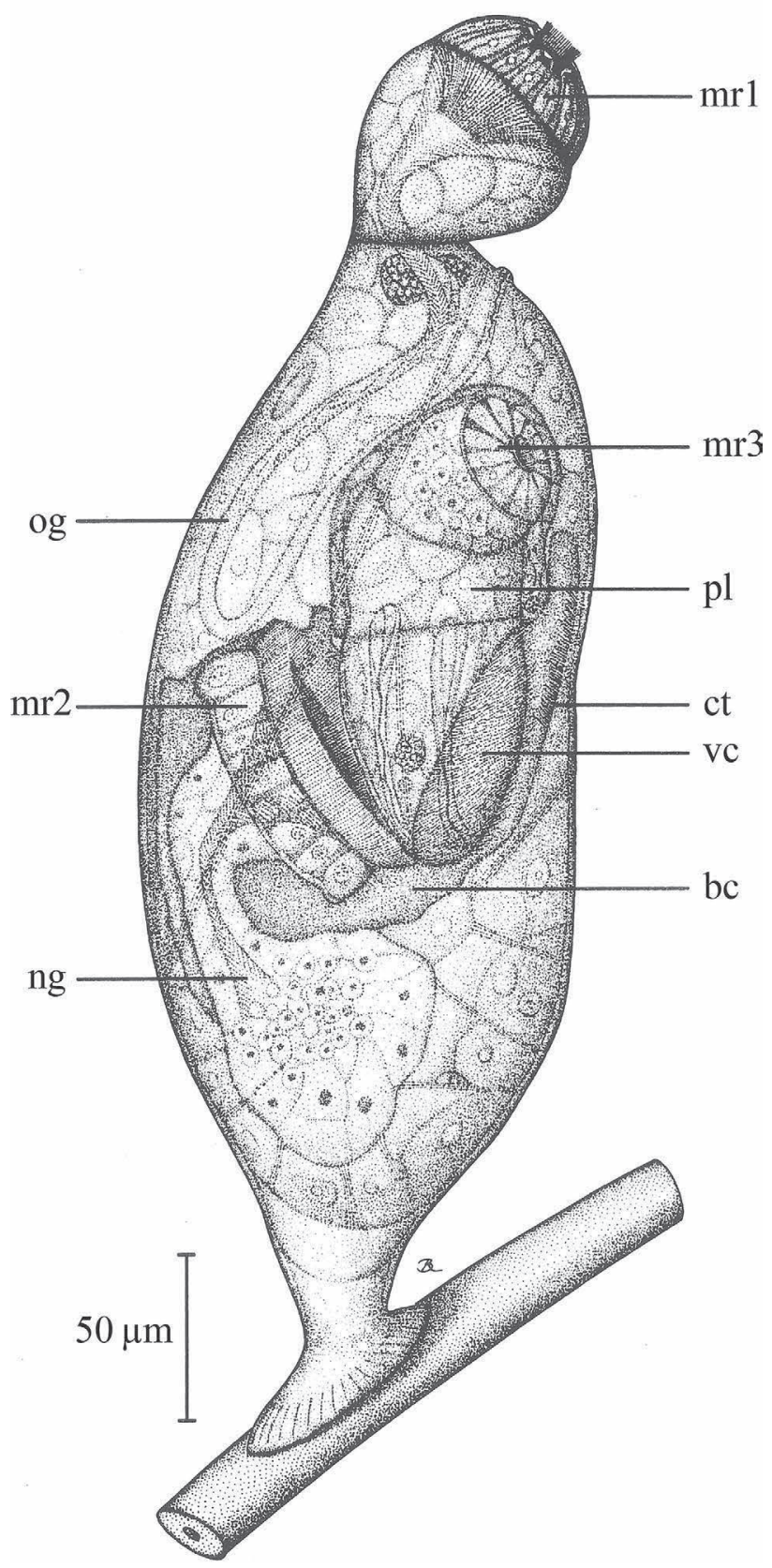

FIGURE 14.5 Young feeding stage of Symbion pandora attached to a host seta from the mouth parts of Nephrops norvegicus. Line drawing from whole mount. The feeding stage individual has a closed mouth ring (mrl) and an old gut (og) reduced in size that provides more space for the developing Pandora larva (pl) inside a brood chamber (bc). An inner bud is in the process of developing a new zooid with a mouth ring (mr2), a ciliated buccal funnel and an immature new gut (ng). The new buccal funnel and the Pandora larva develop inside the same brood chamber (bc) lined with a thin cuticle except at the anal side where cilia tufts (ct) are present. The anterior part of the Pandora larva has a ventral ciliated disc (vc), while the posterior part contains budding cells developing another new feeding stage, which is evident be the presence of a third mouth ring (mr3). (Reproduced with permission from Funch and Kristensen, Cycliophora. In Microscopic Anatomy of Invertebrates, edited by F. W. Harrison and R. M. Woollacott, 409-474. New York etc.: Wiley-Liss Inc., published 1997.)

attached to the mouth parts of the host contain the early developing embryo. Later the cells of the female degenerate, while the embryo inside develops a characteristic chordoid organ. This results in a stage named the chordoid cyst, which consists of a chordoid larva contained in an ovoid case originating from the body cuticle of the female (Figure 14.2). It has been suggested that chordoid larvae typically hatch stimulated by changes in external conditions such as host molting or death (Funch and Kristensen 1999; Kristensen and Funch 2002). 


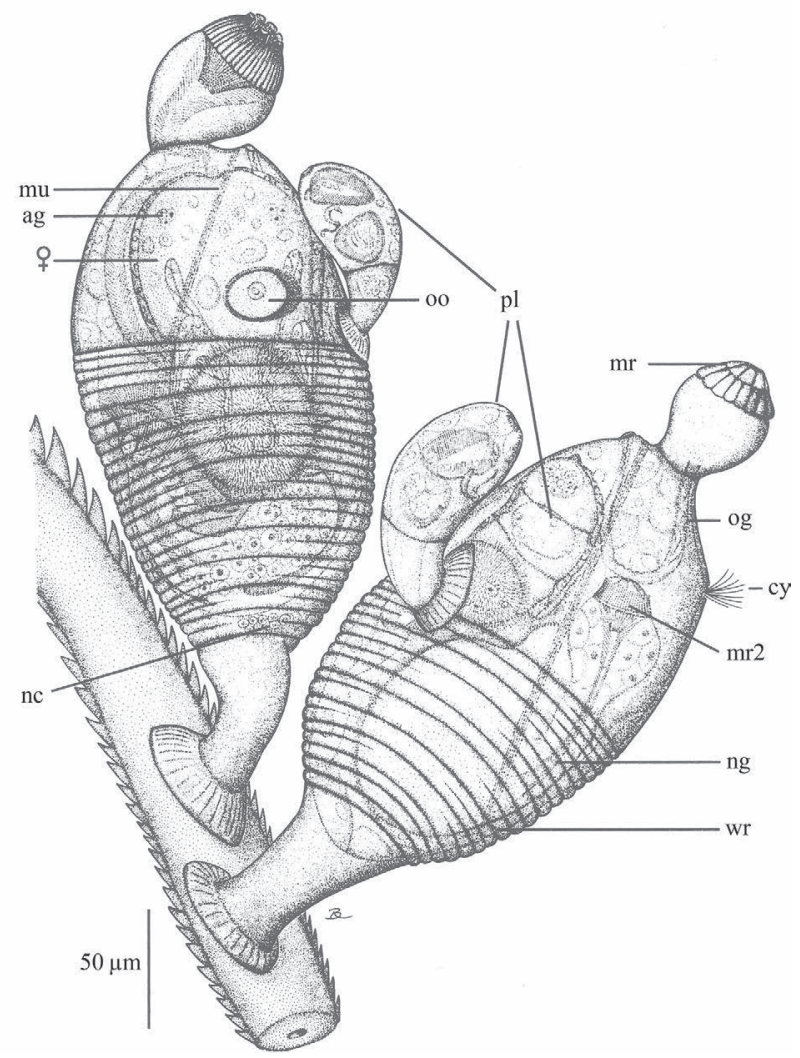

FIGURE 14.6 Two old feeding stages of Symbion pandora with numerous cuticular wrinkles (wr) and a Prometheus larva (pl) attached. Line drawing from whole mount. The feeding stages are attached to a host seta from the mouth parts of Nephrops norvegicus. Right feeding stage with degenerated gut and a Prometheus larva developing in the brood chamber. Left feeding stage with developing female inside the brood chamber. ag, accessory genital glands; cy, cyanobacteria; mr and mr2, mouth ring; mu, muscle; nc, necrotic cells; ng, new gut; og, old gut; oo, oocyte. (Reproduced with permission from Funch and Kristensen, Cycliophora. In Microscopic Anatomy of Invertebrates, edited by F. W. Harrison and R. M. Woollacott, 409-474. New York etc.: Wiley-Liss Inc., published 1997.)

\subsection{ANATOMY}

Cycliophorans are bilaterally symmetrical and acoelomate metazoans with a well-differentiated cuticle that apically has polygonal sculpturing. The feeding stages are sessile and vary in length from about 0.2 to $1 \mathrm{~mm}$. The body of the feeding stage is divided into a distal buccal funnel, a short, slender neck, a trunk, a stalk and an adhesive disc basally that ensures a permanent attachment to the mouth parts of the crustacean host (Figure 14.4a). A few longitudinal muscles are present in the buccal funnel and trunk, but circular body wall muscles are absent (Neves, Kristensen et al. 2009; Neves, Cunha et al. 2010). The broader and distal part of the bell-shaped buccal funnel carries a radially symmetrical ciliated mouth ring that is used in filter feeding when it is everted (Figure 14.4c). Contraction of myoepithelial cells of the mouth ring results in inversion of the mouth ring that directs the cilia into the buccal cavity and closes the mouth opening.

The gut is U-shaped and lined with multiciliated cells. The anterior part of the digestive tract consists of a large mouth opening, the buccal funnel and a narrow S-shaped esophagus. The esophagus leads to an enlarged stomach containing secretory cells that reduce the stomach lumen to lacunae (Figure 14.4b). The tract narrows and bends into a U-turn that leads to an ascending intestine that opens distally in a slitlike transverse opening on the trunk close to the narrow neck (Figure 14.4c). An anal sphincter is present. This opening also serves as an exit for the brooded stages. The whole feeding apparatus including the buccal funnel is repeatedly regenerated from undifferentiated cells basal to the U-turn of the gut by internal budding. Each replacement of the old zooid with a new zooid leaves a wrinkle in the cuticle, and the number of cuticular scars indicates the age of the feeding stage individual. The youngest feeding stages have a smooth cuticle without wrinkles (Figure 14.5), while old feeding stages have many wrinkles (Figure 14.6). Brood chambers in feeding stages are lined with cuticle and contain fluid circulated by specific cilia (Figure 14.5). A brooded stage is fixed in the brood chamber with the anterior end directed toward the basal part of the maternal feeding stage, while the posterior part is connected to a placenta-like structure (Funch and Kristensen 1997).

The Pandora larva, the Prometheus larva and the female are smaller than the feeding stages and range in size between 80 and $200 \mu \mathrm{m}$. Their bodies are ovoid with presumed sensory organs consisting of bundles of paired long stiff ciliary organs anteriorly and a median ciliated pore posteriorly. The 


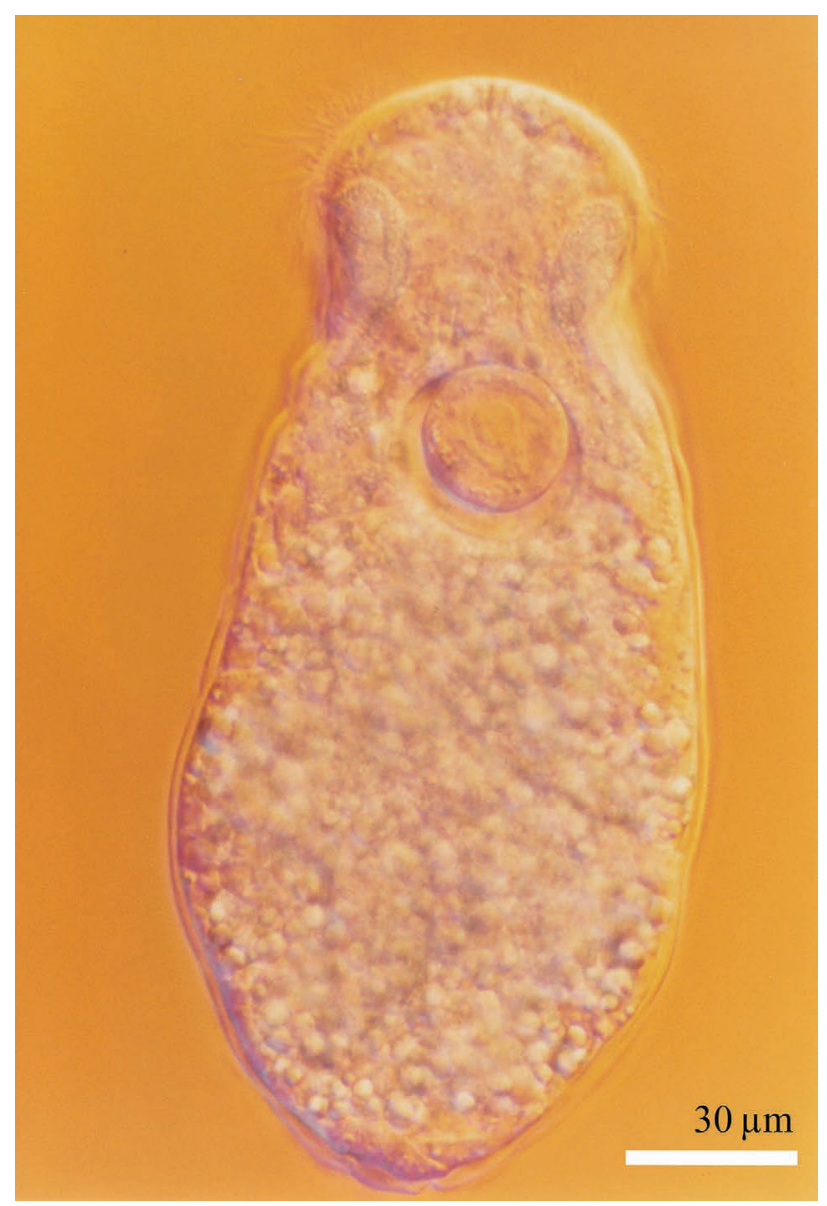

FIGURE 14.7 Female of Symbion pandora just released from the brood chamber of the maternal feeding stage. The upper part shows the anterior end characterized externally by the presence of motile longer stiff sensoria and shorter cilia that form the ventral ciliated disc. Gland cells are present laterally. A single oocyte is situated medially just posterior to the ciliated disc. DIC.

nervous system in these stages consists of a dorsal cerebral ganglion with a pair of lateral clusters of perikarya connected by a commissural neuropil and a pair of ventral longitudinal neurites (Neves, Kristensen et al. 2010). Anteriorly, dorsal and lateral gland cells with elongated gland necks with outlets in the area of the ventral ciliated sole are present. A digestive tract is lacking. After liberation from the feeding stage brood chamber, they have a brief motile phase. The locomotion is by ciliary gliding using an anteroventral ciliated sole (Funch and Kristensen 1997). Settlement and transition from free stages to the sessile stage involve secretion of the gland content over the ciliated sole that becomes the adhesive disc.

The males are the smallest life cycle stage, with an ovoid body, only around $30-40 \mu \mathrm{m}$ long. They also possess an anteroventral sole for ciliary gliding, but in addition, they have two characteristic structures absent in the other life cycle stages. Their external ciliation includes a frontal ciliated field, and posteriorly a sickle-shaped penis is present. The penis is hidden in a ventral pouch but can be protruded (Obst and Funch 2003; Neves, da Cunha, Funch et al. 2010). They have a well-developed body wall musculature, a relatively large cerebral ganglion that occupies most of the anterior body and a pair of ventral neurites (Obst and Funch 2003; Neves, Kristensen et al. 2010).

The chordoid cysts and chordoid larvae are named after a characteristic longitudinal rod of 40-50 cylindrical muscle cells with a central vacuole surrounded by myofilaments - the chordoid organ (Funch 1996). The chordoid larvae are 150-210 $\mu \mathrm{m}$ long and have more external ciliation than any other cycliophoran life cycle stage (Figure 14.8). The ventral body is ciliated with two anterior ciliated bands followed by ciliated field separated from a foot with ventral ciliation. A free chordoid larva both swims and moves along the substrate by ciliary crawling. It has a pair of protonephridia, even though excretory organs are unknown in the other life cycle stages. The protonephridium consists of a single multiciliated terminal cell and at least one duct cell (Funch 1996). The nervous system consists of a dorsal bilobed cerebral ganglion and two paired longitudinal nerves (Neves, da Cunha, Kristensen et al. 2010). Presumed sensory organs include a pair of dorsal ciliated organs and a pair of lateral ciliated pits. A digestive tract is absent. 


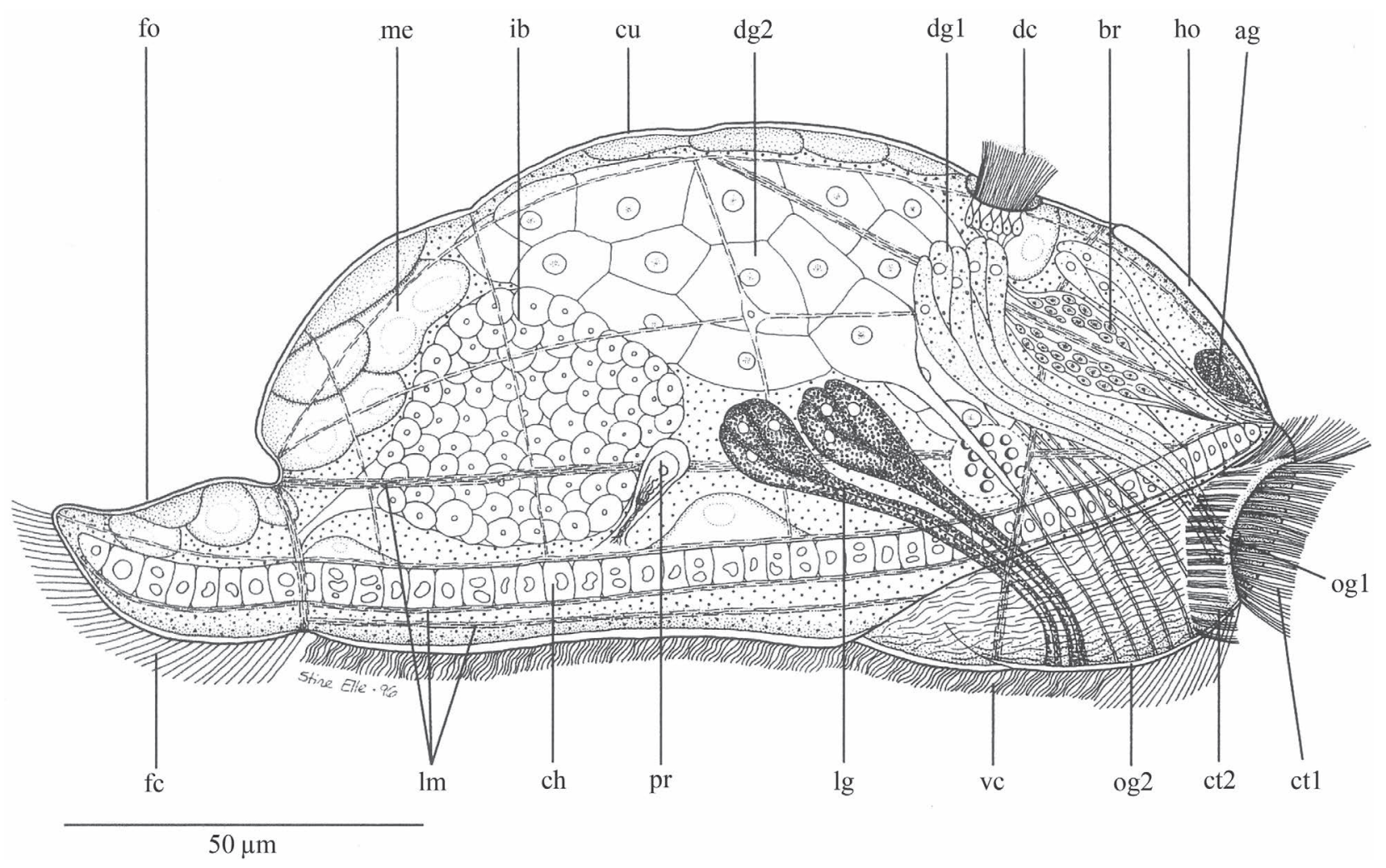

FIGURE 14.8 Chordoid larva of Symbion pandora, lateral view, line drawing from whole mount. The lateral and dorsal integument has an apical cuticle (cu) that dorsal to the brain forms a more rigid hood (ho). Posterior dorsal glands (dg2) with long gland necks extend into a ventral outlet complex (og2). Shorter dorsal glands (dgl), just posterior to the brain (br), extend into a smaller outlet complex (ogl) anteriorly. ag, anterior glands; ch, chordoid organ; ctl and ct2, ciliated band 1 and 2; dc, dorsal ciliated organ; fc, foot cilia; fo, foot; ib, inner bud; lg, lateral gland; lm, longitudinal muscles; me, mesenchyme; pr, protonephridium; vc, ventral cilia. (Reproduced with permission from Funch, the chordoid larva of Symbion pandora [Cycliophora] is a modified trochophore, Wiley-Liss Inc., published 1996.)

\subsection{GENOMIC DATA}

Genomic data on cycliophorans are scarce. However, a transcriptome is available for Symbion americanus generated from a single starved feeding stage individual (Laumer et al. 2015). For $S$. pandora, both transcriptomes and an EST library are available (Hejnol et al. 2009; Neves et al. 2017). Gene expression analysis showed that more than $10 \%$ of the genes were expressed differentially in $S$. pandora, when feeding stage individuals without attached Prometheus larvae (asexual phase) were compared with those with attached Prometheus larvae (sexual phase). Genes related to protein folding and RNA processing and splicing were upregulated in the asexual phase, while those involved in signal transduction and neurotransmission were upregulated in the sexual phase (Neves et al. 2017).

\subsection{FUNCTIONAL APPROACHES: TOOLS FOR MOLECULAR AND CELLULAR ANALYSES}

Ultrastructural studies of Cyliophora were applied and included in the first description of Symbion pandora (Funch and Kristensen 1995) and have been used to characterize various cell types (Funch 1996; Funch and Kristensen 1997).
Cycliophoran cell types include multiciliated epidermal cells with compound cilia and erect microvilli, various types of unicellular glands especially in the free stages, different types of nerve cells and ciliated sensory organs, three types of cells in the protonephridia, strand-like cross-striated muscle cells, vacuolated cylindrical muscle cells of the chordoid organ, mesenchyme cells with large vacuoles with lipids and undifferentiated cells with large nuclei that divide and form the inner buds.

Immunoreactivity studies using fluorescence-coupled antibodies has given deeper insights into the anatomy and function of Cycliophora. The myoanatomy of all stages in the cycliophoran life cycle has been investigated using fluorescence-coupled phalloidin to label filamentous F-actin (Neves et al. 2008; Neves, Kristensen et al. 2009; Neves, Cunha et al. 2010), while the neuroanatomy of Cycliophora has been studied with antibodies directed for a number of markers such as serotonin, synapsin and FMRFamide (Wanninger 2005; Neves, da Cunha, Kristensen et al. 2010; Neves, Kristensen et al. 2010).

The standard fragment of the mitochondrial cytochrome c oxidase subunit I (COI) gene has been used for both species identification and phylogeographic analyses (Obst et al. 2005). Microsatellite loci have not been applied or characterized yet. 


\subsection{CHALLENGING QUESTIONS BOTH IN ACADEMIC AND APPLIED RESEARCH}

One of the challenging questions that remain to be answered is the phylogenetic position of Cycliophora inside Spiralia. Phylogenetic affinities to Bryozoa and Entoprocta were suggested when Cycliophora was first described (Funch and Kristensen 1995), and later a sister group relationship between Entoprocta and Cycliophora was proposed (Funch and Kristensen 1997; Zrzavy et al. 1998; Sørensen et al. 2000). These suggestions were supported by limited and ambiguous morphological characters such as the presence of asexual reproduction by internal budding, complete nervous system degeneration during the transition and settlement from smaller free motile life cycle stages to sessile larger stages and mushroom-shaped extensions of the basal lamina into the epidermis. An alternative hypothesis was proposed based on only molecular data (18S rRNA), namely Syndermata (Rotifera + Acanthocephala) as sister group to Cycliophora (Winnepenninckx et al. 1998). This relationship to gnathiferan taxa was later supported in a number of phylogenetic analyses (Giribet et al. 2000; Peterson and Eernisse 2001; Zrzavy et al. 2001; Zrzavy 2003; Giribet et al. 2004). In the latter study based on four molecular loci, the phylogenetic position of Cycliophora was uncertain, but it tended to support a relationship to Syndermata (Rotifera + Acanthocephala), but the morphological data supporting this relationship were weak (Funch et al. 2005), although Wanninger (2005) suggested similarities in myoanatomy of the cycliophoran chordoid larva and certain rotifers. Phylogenetic analyses using more molecular data resurrected the cycliophoran affinity to entoprocts (Passamaneck and Halanych 2006; Paps et al. 2009), enforced by phylogenomic analyses based on expressed sequence tags (Hejnol et al. 2009; Nesnidal et al. 2013) and transcriptomes (Laumer et al. 2015; Kocot et al. 2017; Laumer et al. 2019). So, while the Cycliophora + Entoprocta clade seems to be well supported, its placement within Spiralia is still unsettled.

There are numerous remaining questions to clarify regarding the life cycle and reproduction in Cycliophora. First, fertilization has never been observed. It is known that females inside brood chambers have oocytes and that free females have embryos (Figures 14.6 and 14.7). It seems likely that fertilization could happen during escape or just after escape of the female, which could explain the preferred site for settlement of the Prometheus larva close to the cloaca opening of the feeding stage, which is also the site of escape of the female. Second, how do free motile stages select the right site for settlement and permanent attachment? Pandora larvae and chordoid larvae seem to prefer the same sites for settlement, namely the food-rich medial areas of the mouth parts of the host. Females prefer to settle upon areas of the mouth parts laterally, maybe because of less mechanical stress and risk of dislocation by the movements of the host, while Prometheus larvae settle upon feeding stages that develop females inside. In spite of these differences in preferred sites to settle, they are all equipped with morphologically similar long stiff ciliary sensory organs that are absent in the sessile stages in the life cycle. Most likely, these sensory organs are involved in sensing and testing if a given substrate is suitable for settlement, but nothing is known about the sensory physiology and type of mechanisms involved. The chordoid larva is equipped with more types of sensory organs, probably because it is a dispersal stage between hosts and uses some of these sensory organs for long-distance sensing. Third, the sex determination system in Cycliophora is unknown. Is haplodiploidy involved, and are cycliophoran dwarf males haploid like the males in, for example, monogonont rotifers? Probably not. In monogonont rotifers, haploid males develop from unfertilized meiotic eggs, while cycliophoran males seem to develop asexually from budding cells. Finally, the mechanism for shifting from asexual to sexual reproduction is unknown. It is unknown if a feeding stage produces a fixed number of Pandora larvae before the shift to sexual reproduction or if it depends on population density of cycliophorans on the host or food availability. Maybe starving of a feeding stage could induce formation of a Prometheus larva instead of a Pandora larva since the latter larva is large and requires more energy to produce.

Dwarf males of Cycliophora consist of less than 200 cells and have only few cell types (Obst and Funch 2003; Neves, Sørensen et al. 2009; Neves and Reichert 2015). Still, the body architecture is relatively complex, with well-developed nervous system, sensory organs, musculature and reproductive organs, which contradicts the general assumption about correlation of complexity of the body plan and the number of cells and cell types (Bell and Mooers 1997). Future exploration of the cycliophoran genome could provide new insights into how high body plan complexity can be achieved with few cells.

\section{ACKNOWLEDGMENTS}

I greatly acknowledge the collaboration with Stine Elle and Birgitte Rubæk and Reinhardt Møbjerg Kristensen producing the line drawings.

\section{BIBLIOGRAPHY}

Andersen, P. F. 1992. Beskrivelse af en ny klasse-Mesoprocta. Master thesis, University of Copenhagen. Copenhagen.

Baker, J. M., P. Funch, and G. Giribet. 2007. Cryptic speciation in the recently discovered American cycliophoran Symbion americanus: Genetic structure and population expansion. Marine Biology 151 (6):2183-2193.

Baker, J. M., and G. Giribet. 2007. A molecular phylogenetic approach to the phylum Cycliophora provides further evidence for cryptic speciation in Symbion americanus. Zoologica Scripta 36 (4):353-359.

Bell, G., and A. O. Mooers. 1997. Size and complexity among multicellular organisms. Biological Journal of the Linnean Society 60 (3):345-363.

Clément, P., and E. Wurdak. 1991. Rotifera. In Microscopic Anatomy of Invertebrates, edited by F. W. Harrison and R. M. Woollacott, 219-297. New York etc.: Wiley-Liss. 
Funch, P. 1996. The chordoid larva of Symbion pandora (Cycliophora) is a modified trochophore. Journal of Morphology 230 (3): 231-263.

Funch, P., and R. M. Kristensen. 1995. Cycliophora is a new phylum with affinities to Entoprocta and Ectoprocta. Nature 378 (6558):711-714.

Funch, P., and R. M. Kristensen. 1997. Cycliophora. In Microscopic Anatomy of Invertebrates, edited by F. W. Harrison and R. M. Woollacott, 409-474. New York etc.: Wiley-Liss.

Funch, P., and R. M. Kristensen. 1999. Cycliophora. In Encyclopedia of Reproduction, edited by Ernst Knobil and Jimmy D. Neill, 800-808. San Diego: Academic Press.

Funch, P., and R. Neves. 2019. Cycliophora. In Miscellaneous Invertebrates, edited by A. Schmidt-Rhaesa, 87-110. Berlin/ Boston: Walter de Gruyter GmbH \& Co. KG.

Funch, P., M. V. Sørensen, and M. Obst. 2005. On the phylogenetic position of Rotifera: Have we come any further? Hydrobiologia 546:11-28.

Funch, P., P. Thor, and M. Obst. 2008. Symbiotic relations and feeding biology of Symbion pandora (Cycliophora) and Triticella flava (Bryozoa). Vie et Milieu-Life and Environment 58 (2):185-188.

Giribet, G., D. L. Distel, M. Polz, W. Sterrer, and W. C. Wheeler. 2000. Triploblastic relationships with emphasis on the acoelomates and the position of Gnathostomulida, Cycliophora, Plathelminthes, and Chaetognatha: A combined approach of 18S rDNA sequences and morphology. Systematic Biology 49 (3):539-562.

Giribet, G., M. V. Sørensen, P. Funch, R. M. Kristensen, and W. Sterrer. 2004. Investigations into the phylogenetic position of Micrognathozoa using four molecular loci. Cladistics 20 (1):1-13.

Hejnol, A., M. Obst, A. Stamatakis, M. Ott, G. W. Rouse, G. D. Edgecombe, P. Martinez, J. Baguna, X. Bailly, U. Jondelius, M. Wiens, W. E. G. Muller, E. Seaver, W. C. Wheeler, M. Q. Martindale, G. Giribet, and C. W. Dunn. 2009. Assessing the root of bilaterian animals with scalable phylogenomic methods. Proceedings of the Royal Society B-Biological Sciences 276 (1677):4261-4270.

Kocot, K. M., T. H. Struck, J. Merkel, D. S. Waits, C. Todt, P. M. Brannock, D. A. Weese, J. T. Cannon, L. L. Moroz, B. Lieb, and K. M. Halanych. 2017. Phylogenomics of Lophotrochozoa with consideration of systematic error. Systematic Biology 66 (2):256-282.

Kristensen, R. M. 2002. An introduction to Loricifera, Cycliophora, and Micrognathozoa. Integrative and Comparative Biology 42 (3):641-651.

Kristensen, R. M., and P. Funch. 2002. Phylum Cycliophora. In Atlas of Marine Invertebrate Larvae, edited by Craig M. Young, M. A. Sewell and M. Rice, 231-240. San Diego, CA: Academic Press.

Laumer, C. E., N. Bekkouche, A. Kerb, F. Goetz, R. C. Neves, M. V. Sørensen, R. M. Kristensen, A. Hejno, C. W. Dunn, G. Giribet, and K. Worsaae. 2015. Spiralian phylogeny informs the evolution of microscopic lineages. Current Biology 25 (15):2000-2006.

Laumer, C. E., R. Fernandez, S. Lemer, D. Combosch, K. M. Kocots, A. Riesgo, S. C. S. Andrade, W. Sterrer, M. V. Sørensen, and G. Giribet. 2019. Revisiting metazoan phylogeny with genomic sampling of all phyla. Proceedings of the Royal Society B-Biological Sciences 286 (1906).

Nesnidal, M. P., M. Helmkampf, A. Meyer, A. Witek, I. Bruchhaus, I. Ebersberger, T. Hankeln, B. Lieb, T. H. Struck, and B. Hausdorf. 2013. New phylogenomic data support the monophyly of Lophophorata and an ectoproct-phoronid clade and indicate that Polyzoa and Kryptrochozoa are caused by systematic bias. BMC Evolutionary Biology 13 .

Neves, R. C., X. Bailly, and H. Reichert. 2014. Are copepods secondary hosts of Cycliophora? Organisms Diversity \& Evolution 14 (4):363-367.

Neves, R. C., M. R. Cunha, P. Funch, R. M. Kristensen, and A. Wanninger. 2010. Comparative myoanatomy of cycliophoran life cycle stages. Journal of Morphology 271 (5):596-611.

Neves, R. C., M. R. da Cunha, P. Funch, A. Wanninger, and R. M. Kristensen. 2010. External morphology of the cycliophoran dwarf male: A comparative study of Symbion pandora and S. americanus. Helgoland Marine Research 64 (3):257-262.

Neves, R. C., M. R. da Cunha, R. M. Kristensen, and A. Wanninger. 2010. Expression of synapsin and co-localization with serotonin and RFamide-like immunoreactivity in the nervous system of the chordoid larva of Symbion pandora (Cycliophora). Invertebrate Biology 129 (1):17-26.

Neves, R. C., J. C. Guimaraes, S. Strempel, and H. Reichert. 2017. Transcriptome profiling of Symbion pandora (phylum Cycliophora): Insights from a differential gene expression analysis. Organisms Diversity \& Evolution 17 (1):111-119.

Neves, R. C., R. M. Kristensen, and P. Funch. 2012. Ultrastructure and morphology of the cycliophoran female. Journal of Morphology 273 (8):850-869.

Neves, R., R. M. Kristensen, and A. Wanninger. 2008. New insights from the myoanatomy of Symbion americanus (phylum Cycliophora) revealed by confocal microscopy and 3D reconstruction software. Journal of Morphology 269 (12):1480-1480.

Neves, R. C., R. M. Kristensen, and A. Wanninger. 2009. Threedimensional reconstruction of the musculature of various life cycle stages of the cycliophoran Symbion americanus. Journal of Morphology 270 (3):257-270.

Neves, R. C., R. M. Kristensen, and A. Wanninger. 2010. Serotonin immunoreactivity in the nervous system of the Pandora larva, the Prometheus larva, and the dwarf male of Symbion americanus (Cycliophora). Zoologischer Anzeiger 249 (1):1-12.

Neves, R. C., and H. Reichert. 2015. Microanatomy and development of the dwarf male of Symbion pandora (phylum Cycliophora): New insights from ultrastructural investigation based on serial section electron microscopy. PLoS One 10 (4).

Neves, R. C., K. J. K. Sørensen, R. M. Kristensen, and A. Wanninger. 2009. Cycliophoran dwarf males break the rule: High complexity with low cell numbers. Biological Bulletin 217 (1):2-5.

Obst, M., and P. Funch. 2003. Dwarf male of Symbion pandora (Cycliophora). Journal of Morphology 255 (3):261-278.

Obst, M., and P. Funch. 2006. The microhabitat of Symbion pandora (Cycliophora) on the mouthparts of its host Nephrops norvegicus (Decapoda: Nephropidae). Marine Biology 148 (5):945-951.

Obst, M., P. Funch, and G. Giribet. 2005. Hidden diversity and host specificity in cycliophorans: A phylogeographic analysis along the North Atlantic and Mediterranean Sea. Molecular Ecology 14 (14):4427-4440.

Obst, M., P. Funch, and R. M. Kristensen. 2006. A new species of Cycliophora from the mouthparts of the American lobster, Homarus americanus (Nephropidae, Decapoda). Organisms Diversity \& Evolution 6 (2):83-97.

Paps, J., J. Baguna, and M. Riutort. 2009. Lophotrochozoa internal phylogeny: New insights from an up-to-date analysis of nuclear ribosomal genes. Proceedings of the Royal Society B-Biological Sciences 276 (1660):1245-1254. 
Passamaneck, Y., and K. M. Halanych. 2006. Lophotrochozoan phylogeny assessed with LSU and SSU data: evidence of lophophorate polyphyly. Molecular Phylogenetics and Evolution 40 (1):20-28.

Peterson, K. J., and D. J. Eernisse. 2001. Animal phylogeny and the ancestry of bilaterians: Inferences from morphology and 18S rDNA gene sequences. Evolution \& Development 3 (3):170-205.

Plaza, M. 2012. Cycliophoran host range. Bulletin of the Peabody Museum of Natural History 53 (2):389-395.

Sørensen, M. V., P. Funch, E. Willerslev, A. J. Hansen, and J. Olesen. 2000. On the phylogeny of the Metazoa in the light of Cycliophora and Micrognathozoa. Zoologischer Anzeiger 239 (3-4):297-318.
Wanninger, A. 2005. Immunocytochemistry of the nervous system and the musculature of the chordoid larva of Symbion pandora (Cycliophora). Journal of Morphology 265 (2):237-243.

Winnepenninckx, B. M. H., T. Backeljau, and R. M. Kristensen. 1998. Relations of the new phylum Cycliophora. Nature 393 (6686):636-638.

Zrzavy, J. 2003. Gastrotricha and metazoan phylogeny. Zoologica Scripta 32 (1):61-81.

Zrzavy, J., V. Hypsa, and D. F. Tietz. 2001. Myzostomida are not annelids: Molecular and morphological support for a clade of animals with anterior sperm flagella. Cladistics 17 (2):170-198.

Zrzavy, J., S. Mihulka, P. Kepka, A. Bezdek, and D. Tietz. 1998. Phylogeny of the Metazoa based on morphological and 18S ribosomal DNA evidence. Cladistics 14 (3):249-285. 